\title{
PPP2R2A wt Allele
}

National Cancer Institute

\section{Source}

National Cancer Institute. PPP2R2A wt Allele. NCI Thesaurus. Code C134507.

Human PPP2R2A wild-type allele is located in the vicinity of 8p21.2 and is approximately $81 \mathrm{~kb}$ in length. This allele, which encodes serine/threonine-protein phosphatase 2A 55 $\mathrm{kDa}$ regulatory subunit $\mathrm{B}$ alpha isoform protein, plays a role in the regulation of protein phosphatase 2 activity. 